\title{
HUBUNGAN PENGETAHUAN DAN SIKAP KELUARGA DENGAN PENERAPAN HIDUP BERSIH DAN SEHAT PADA TATANAN RUMAH TANGGA DI DESA PAYANGAN WILAYAH KERJA PUSKESMAS MARGA I TABANAN
}

\section{THE CORRELATION OF KNOWLEDGE AND ATTITUDE OF FAMILY WITH APPLICATION OF CLEAN AND HEALTHY LIFE ON THE ORDER HOUSEHOLD IN PAYANGAN VILLAGE THE WORKING AREA OF PUSKESMAS MARGA I TABANAN}

\author{
Ni Komang Lisa Anggraeni ${ }^{1}$, Ni Wayan Suniyadewi ${ }^{1}$, Ni Luh Putu Devhy ${ }^{1}$ \\ ${ }^{1}$ STIKes Wira Medika PPNI Bali
}

\begin{abstract}
ABSTRAK
Pendahuluan: Perilaku Hidup Bersih dan Sehat (PHBS) merupakan sekumpulan perilaku dari masyarakat agar mampu menolong dirinya sendiri dibidang kesehatan. Di Desa Payangan diketahui bahwa rumah tangga yang telah mempraktikkan PHBS baru mencapai $32,5 \%$ dari target $75 \%$. Pengetahuan dan sikap dibutuhkan oleh keluarga untuk menerapkan PHBS dengan baik. Penelitian ini bertujuan mengetahui hubungan pengetahuan dan sikap keluarga dengan penerapan hidup bersih dan sehat pada tatanan rumah tangga di Desa Payangan Marga Tabanan. Metode: Desain penelitian adalah deskriptif korelasi dengan pendekatan cross sectional. Jumlah sampel 43 responden diambil dengan teknik proportional stratified random sampling. Analisa data menggunakan uji Rank Spearman. Hasil: ada hubungan yang signifikan antara pengetahuan keluarga dengan penerapan hidup bersih dan sehat p-value 0,001 dan ada hubungan yang signifikan antara sikap keluarga dengan penerapan hidup bersih dan sehat p-value 0,000. Diskusi: diharapkan petugas kesehatan dapat meningkatkan pengetahuan dan sikap masyarakat terkait PHBS melalui penyuluhan, penempelan poster,dll.
\end{abstract}

Kata Kunci: Pengetahuan, Sikap, Penerapan hidup bersih dan sehat

\section{ABSTRACT}

Introduction: Clean and Healthy Life Behavior (PHBS) is a set of behaviors of the community to be able to help themselves in the field of health. In Payangan village note that households have been practicing a new PHBS reached $32.5 \%$ of the target of $75 \%$. Knowledge and attitudes required by families to implement PHBS well. The aims of this study was to determine the correlation of knowledge and attitude of family with application of clean and healthy life on the order household in Payangan Marga Tabanan. Method: The design of research was a descriptive correlation with cross sectional approach. The total sample of 43 respondents were taken by proportional stratified random sampling. Data analysis used Rank Spearman test. Result: There was a significant correlation between family knowledge with the application of clean and healthy life p-value 0.001 and there was a significant correlation between family attitudes with the application of clean 
and healthy life p-value 0,000. Discussion: Expected to health workers to improve knowledge and attitudes related to PHBS through counseling, pasting posters, etc.

Keyword : Knowledge, Attitudes, Application of Clean and Healthy life

\begin{tabular}{ll}
\hline Alamat Koresponden & : Dusun Baturiti Tengah, Desa Baturiti, Kerambitan, Tabanan \\
Email & $:$ komanglisa10@gmail.com \\
\hline
\end{tabular}

\section{PENDAHULUAN}

Sasaran Pembangunan Indonesia tahun 2015-2030 mempunyai 17 sasaran SDGs, yaitu pemberantasan kemiskinan, nol kelaparan, kesehatan yang baik, pendidikan berkualitas, kesehatan jender, air bersih dan sanitasi, energi bersih dan terjangkau, kerja layak dan pertumbuhan ekonomi, industri inovasi dan infrastruktur, pengurangan kesenjangan, kota dan masyarakat berkelanjutan, komsumsi yang bertanggung jawab, aksi perubahan iklim, kehidupan bawah laut, kehidupan di darat, perdamaian dan keadilan, kemitraan demi mencapai tujuan. Mendukung sasaran SDGs terutama pada sasaran kesehatan yang baik, air bersih dan sanitasi, maka salah satu upaya kesehatan pokok atau misi sektor kesehatan adalah mendorong masyarakat untuk menerapkan Perilaku Hidup Bersih dan Sehat (Rakorpop Kemenkes RI, 2015)

Perilaku Hidup Bersih dan Sehat (PHBS) merupakan sekumpulan perilaku yang dipraktikkan atas dasar kesadaran sebagai hasil pembelajaran, yang menjadikan keluarga, kelompok dan masyarakat mampu menolong dirinya sendiri di bidang kesehatan (Kemenkes RI, 2015). Berdasarkan rapat koordinasi promosi kesehatan tingkat nasional (2007) ada 10 indikator PHBS di tatanan rumah tangga terdiri dari persalinan di tolong oleh tenaga kesehatan, pemberian asi eksklusif, menimbang balita setiap bulan, menggunakan air bersih, cuci tangan dengan sabun dan air bersih, menggunakan jamban sehat, pemberantasan jentik nyamuk di rumah, makan buah dan sayur setiap hari, melakukan aktivitas fisik setiap hari, tidak merokok di dalam rumah (Proverawati dan Rahmawati, 2012).

Riset Kesehatan Dasar (2013) proporsi Nasional rumah tangga dengan PHBS baik masih jauh dari target sebesar 32,3\%. Rencana Strategi tahun 2015, Kementerian Kesehatan tahun 2015-2019 mentargetkan 75\% rumah tangga sudah memperaktekkan PHBS. Pada tahun 2015 di Provinsi Bali capaian rumah tangga ber-PHBS belum mencapai target nasional dengan capaian sebesar 74,33\%. Cakupan rumah tangga ber-PHBS tertinggi di Kabupaten Klungkung 81,80\% dan Kota Denpasar 81,48\%, sedangkan cakupan terendah Kabupaten Karangasem $72,09 \%$ dan Kabupaten Tabanan 60,82\% (Dinas Kesehatan Provinsi Bali, 2016).

Berdasarkan data Dinas Kesehatan Kabupaten Tabanan (2016), rumah tangga ber-PHBS paling rendah adalah Wilayah Kerja Puskesmas Marga 1, dimana rumah tangga ber-PHBS ini mengalami penurunan pencapaian yaitu tahun 2014 sebesar $65,10 \%$, tahun 2015 sebesar 57,6\%, dan tahun 2016 sebesar 8,6\%. Penurunan capaian rumah tangga ber-PHBS ini disebabkan karena pemahaman dan kesadaran masyarakat tentang pentingnya PHBS di rumah tangga masih kurang, sehingga terjadi peningkatan kasus DBD drastis dari tahun 2015 ke 2016, ISPA tinggi, dan ada kesenjangan dari pencapaian target pemberian ASI eksklusif (Puskesmas Marga I, 2016). 
Di Wilayah Kerja Puskesmas Marga 1 sendiri rumah tangga yang ber-PHBS terendah adalah Desa Payangan sebesar 32,5\% dari target 75\%. Cakupan indikator PHBS tatanan rumah tangga di Desa Payangan Marga yang belum mencapai target Puskesmas yaitu pemberian ASI eksklusif sebesar $60 \%$, mencuci tangan dengan air bersih dan sabun sebesar $60 \%$, memberantas jentik nyamuk sebesar $60 \%$, tidak merokok di dalam rumah sebesar 70\% (Puskesmas Marga I, 2016).

Rendahnya PHBS tersebut akan berdampak terhadap masalah kesehatan, dimana penyakit berbasis lingkungan masih menjadi masalah kesehatan masyarakat. ISPA, Diare dan Demam Berdarah Dengue (DBD) adalah penyakit berbasis lingkungan yang selalu berada diurutan teratas 10 penyakit yang paling umum (Riskesdas, 2013). Menurut WHO (2011), setiap tahunnya sekitar 2,2 juta orang di negara berkembang terutama anak-anak meninggal dunia akibat berbagai penyakit yang disebabkan oleh kurangnya air minum yang aman, sanitasi dan hygiene yang buruk. Terdapat bukti bahwa pelayanan sanitasi yang memadai dan persediaan air yang aman dapat menekan angka kematian akibat diare sampai $65 \%$, serta penyakit lainnya sebanyak 26\%. Di Indonesia prevalensi Infeksi Saluran Pernafasan Akut (ISPA) ditemukan sebesar 25,0\%. Karakteristik penduduk dengan ISPA tertinggi terjadi pada kelompok umur 1-4 tahun sebesar 25,8\% (Riskesdas, 2013).

Berdasarkan data Dinas Kesehatan Provinsi Bali (2016), dilaporkan terjadi peningkatan jumlah penderita DBD pada tahun 2014 sebanyak 8.629 kasus $(0,21 \%)$ dengan jumlah kematian 17 orang, tahun 2015 sebanyak 10.759 kasus $(0,26 \%)$ dengan jumlah kematian 29 orang, dan tahun 2016 sebanyak 20.467 kasus $(0,51 \%)$ dengan kematian 61 orang, hal ini disebabkan karena masih buruknya lingkungan fisik maupun perilaku masyarakat untuk hidup bersih dan sehat. Kabupaten Tabanan merupakan Kabupaten dengan kejadian KLB keempat di Provinsi Bali, dengan kejadian diare sebesar 2,15\% (9.370 kasus) dan kejadian DBD sebesar 0,21\% (918 kasus) (Dinas Kesehatan Kabupaten Tabanan, 2016).

Berdasarkan laporan registrasi harian Puskesmas Marga 1 (2016) dari 9 dusun yang ada di Desa Payangan, kunjungan pasien terbanyak terkait dengan kejadian diare dan DBD yang dilaporkan tinggi berasal dari dusun Alas Sandan dan Alas Teruna, sedangkan kunjungan pasien ISPA terbanyak berasal dari dusun Payangan Tengah. Menurut keterangan dari petugas promosi kesehatan di Puskesmas Marga 1, ketiga dusun tersebut merupakan dusun-dusun dengan rumah tangga ber-PHBS kurang, hal ini didukung oleh gambaran kondisi dan sanitasi lingkungan pada saat petugas melakukan survei, dimana ditemukan masih banyak warga yang membuang limbah kamar mandi dan sisa dapur ke kebun yang berada disebelah rumah mereka, serta sampah dibuang begitu saja ke kebun yang nantinya akan menjadi tempat bersarangnya nyamuk (Puskesmas Marga I, 2016).

Kurangnya pelaksanaan PHBS tersebut, dapat ditingkatkan apabila keluarga memiliki pengetahuan yang memadai dan sikap positif untuk menerapkan hidup bersih dan sehat di tatanan rumah tangga. Pengetahuan atau kognitif merupakan domain yang sangat penting dalam membentuk tindakan seseorang (over behavior) (Wawan dan Dewi, 2010). Perilaku yang di dasari oleh pengetahuan akan lebih langgeng dari perilaku yang tidak di dasari oleh pengetahuan (Notoatmodjo, 2007). Sikap merupakan organisasi pendapat, keyakinan seseorang mengenai suatu objek atau situasi yang disertai adanya perasaan tertentu, dan memberikan dasar pada orang tersebut untuk berespon atau berperilaku dalam cara tertentu yang dipilihnya 
(Wawan dan Dewi, 2010). Kastari (2016) dalam penelitiannya menyatakan responden yang memiliki sikap baik akan diikuti dengan tindakan baik juga. Keadaan ini sesuai dengan teori yang menyatakan bahwa sikap merupakan salah satu faktor predisposisi seseorang untuk bertindak.

Berdasarkan Hasil Studi Pendahuluan yang dilakukan di Dusun Alas Teruna dan Alas Sandan Desa Payangan Marga pada tanggal 05-02-2017, peneliti melakukan wawancara terhadap 10 responden tentang PHBS, diketahui 6 responden sama sekali tidak memahami tentang PHBS, 4 responden memahami tentang PHBS. 4 responden tidak mengetahui tentang pemberian ASI eksklusif, 5 responden membersihkan tangan dengan air saja tanpa menggunakan sabun dan 3 responden hanya mencuci tangan bila hendak makan saja, serta tidak mengetahui akibat yang ditimbulkan jika tidak mencuci tangan. 6 responden menguras bak mandi pada waktu tertentu, 4 responden tidak pernah menguras bak mandi dan tidak pernah melakukan pemberantasan jentik nyamuk. 5 responden juga tidak mempermasalahkan kebiasaan anggota keluarga menggantung pakaian dibelakang pintu dan beranggapan tidak akan menjadi tempat bersarangnya nyamuk. Berdasarkan hasil observasi terlihat 8 orang yang merokok, 4 diantaranya merokok di dalam rumah saat sedang bersama anggota keluarganya.

Berdasarkan fenomena dan data yang telah diuraikan tersebut menjadikan dasar bagi peneliti untuk mengetahui hubungan pengetahuan dan sikap keluarga dengan penerapan hidup bersih dan sehat pada tatanan rumah tangga di Desa Payangan wilayah kerja Puskesmas Marga I Tabanan.

\section{BAHAN DAN METODE}

Rancangan penelitian yang digunakan dalam penelitian ini adalah deskriptif korelational. Desain ini menggunakan pendekatan cros sectional untuk melihat hubungan pengetahuan dan sikap keluarga dengan penerapan hidup bersih dan sehat pada tatanan rumah tangga di Desa Payangan wilayah kerja Puskesmas Marga I Tabanan yang dilaksanakan pada tanggal 07 - 17 Mei 2017. Sampel penelitian ini dipilih sebanyak 43 orang responden menggunakan teknik sampling probability sampling dengan proportional stratified random sampling berdasarkan kriteria inklusi dan eksklusi yang sudah ditentukan. Instrument yang digunakan dalam penelitian ini yaitu kuisioner pengetahuan, sikap dan penerapan PHBS di tatanan rumah tangga. Data dianalisis mengunakan uji rank spearman.

\section{HASIL}

Analisa yang dilakukan memperoleh hasil sebagai berikut:

Tabel 1. Karakteristik Responden Berdasarkan Umur

\begin{tabular}{ccc}
\hline Umur & F & \% \\
\hline $\mathbf{1 7 - 2 5}$ tahun & 10 & 22,3 \\
\hline $\mathbf{2 6 - 3 5}$ tahun & 29 & 67,4 \\
\hline $\mathbf{3 6 - 4 5}$ tahun & 4 & 9,3 \\
\hline Total & 43 & 100 \\
\hline
\end{tabular}


Tabel 2. Karakteristik Responden Berdasarkan Pendidikan

\begin{tabular}{ccc}
\hline Pendidikan & F & \% \\
\hline SD & 2 & 4,7 \\
\hline SMP & 22 & 51,2 \\
\hline SMA & 16 & 37,2 \\
\hline Perguruan Tinggi & 3 & 7,0 \\
\hline Total & 43 & 100
\end{tabular}

Tabel 3. Karakteristik Responden Berdasarkan Pengetahun

\begin{tabular}{ccc}
\hline Pengetahuan & F & \% \\
\hline Baik & 19 & 44,2 \\
\hline Cukup & 21 & 48,8 \\
\hline Kurang & 3 & 7,0 \\
\hline Total & 43 & 100 \\
\hline
\end{tabular}

Tabel 4. Karakteristik Responden Berdasarkan Sikap

\begin{tabular}{ccc}
\hline Sikap & F & \% \\
\hline Baik & 16 & 37,2 \\
\hline Cukup & 25 & 58,1 \\
\hline Kurang & 2 & 4,7 \\
\hline Total & 43 & 100 \\
\hline
\end{tabular}

Tabel 5. Karakteristik Responden Berdasarkan Penerapan

\begin{tabular}{ccc}
\hline Penerapan & F & \% \\
\hline Baik & 8 & 18,6 \\
\hline Cukup & 20 & 46,5 \\
\hline Kurang & 15 & 34,9 \\
\hline Total & 43 & 100 \\
\hline
\end{tabular}

Tabel 6. Hubungan Pengetahuan Keluarga dengan Penerapan Hidup Bersih dan Sehat Pada Tatanan Rumah Tangga

\begin{tabular}{|c|c|c|c|c|c|c|c|c|c|c|}
\hline \multirow[t]{3}{*}{ Pengetahuan } & \multicolumn{6}{|c|}{$\begin{array}{c}\text { Penerapan Hidup Bersih dan } \\
\text { Sehat }\end{array}$} & \multicolumn{2}{|c|}{ Total } & $\mathbf{r}$ & $\begin{array}{c}\mathrm{p}- \\
\text { value }\end{array}$ \\
\hline & \multicolumn{2}{|c|}{ Baik } & \multicolumn{2}{|c|}{ Cukup } & \multicolumn{2}{|c|}{ Kurang } & \multirow[b]{2}{*}{$\mathbf{F}$} & \multirow[b]{2}{*}{$\%$} & \multirow{6}{*}{0,477} & \multirow{6}{*}{0,001} \\
\hline & $\mathbf{F}$ & $\%$ & $\mathbf{F}$ & $\%$ & $\mathbf{F}$ & $\%$ & & & & \\
\hline Baik & 6 & 14,0 & 11 & 25,6 & 2 & 4,7 & 19 & 44,2 & & \\
\hline Cukup & 2 & 4,7 & 8 & 18,6 & 11 & 25,6 & 21 & 48,8 & & \\
\hline Kurang & 0 & 0,0 & 1 & 2,3 & 2 & 4,7 & 3 & 7,0 & & \\
\hline Total & 8 & 18,6 & 20 & 46,5 & 15 & 34,9 & 43 & 100,0 & & \\
\hline
\end{tabular}


Berdasarkan hasil analisis korelasi Rank Spearman dengan tingkat kesalahan $5 \%(0,05)$ hubungan antara pengetahuan dengan penerapan hidup bersih dan sehat pada tatanan rumah tangga didapatkan nilai $\mathrm{p}$ value $=0,001(\mathrm{p}<0,05)$ maka Ho ditolak dan hipotesis penelitian (Ha) diterima, yang artinya ada hubungan yang signifikan antara variabel pengetahuan keluarga dengan penerapan hidup bersih dan sehat pada tatanan rumah tangga di Desa Payangan Wilayah Kerja Puskesmas Marga I Tabanan. Nilai kekuatan korelasi sebesar 0,477 (kekuatan sedang) dan arah korelasi positif $(+)$ artinya semakin baik pengetahuan keluarga terkait dengan hidup bersih dan sehat, maka semakin baik pula penerapan hidup bersih dan sehatnya, begitu sebaliknya semakin kurang pengetahuan keluarga terkait dengan hidup bersih dan sehat, maka akan semakin kurang juga penerapan hidup bersih dan sehat dari keluarga tersebut.

Tabel 7. Hubungan Sikap Keluarga dengan Penerapan Hidup Bersih dan Sehat Pada Tatanan Rumah Tangga

\begin{tabular}{|c|c|c|c|c|c|c|c|c|c|c|}
\hline \multirow[t]{3}{*}{ Sikap } & \multicolumn{6}{|c|}{$\begin{array}{c}\text { Penerapan Hidup Bersih dan } \\
\text { Sehat }\end{array}$} & \multirow{2}{*}{\multicolumn{2}{|c|}{ Total }} & \multirow[t]{3}{*}{$\mathbf{r}$} & \multirow[t]{3}{*}{$\begin{array}{c}\text { p- } \\
\text { value }\end{array}$} \\
\hline & \multicolumn{2}{|c|}{ Baik } & \multicolumn{2}{|c|}{ Cukup } & \multicolumn{2}{|c|}{ Kurang } & & & & \\
\hline & $\mathbf{F}$ & $\%$ & $\mathbf{F}$ & $\%$ & $\mathbf{F}$ & $\%$ & $\mathbf{F}$ & $\%$ & & \\
\hline Baik & 6 & 14,0 & 10 & 23,3 & 0 & 0,0 & 16 & 37,2 & & \\
\hline Cukup & 2 & 4,7 & 8 & 18,6 & 15 & 34,9 & 25 & 58,1 & 0,524 & 0,000 \\
\hline Kurang & 0 & 0,0 & 2 & 4,7 & 0 & 0,0 & 2 & 4,7 & & \\
\hline Total & 8 & 18,6 & 20 & 46,5 & 15 & 34,9 & 43 & 100,0 & & \\
\hline
\end{tabular}

Berdasarkan hasil analisis korelasi Rank Spearman dengan tingkat kesalahan $5 \%(0,05)$ hubungan antara sikap dengan penerapan hidup bersih dan sehat pada tatanan rumah tangga didapatkan nilai $\mathrm{p}$ value $=0,000(\mathrm{p}<0,05)$ maka Ho ditolak dan hipotesis penelitian (Ha) diterima, yang artinya ada hubungan yang signifikan antara variabel sikap keluarga dengan penerapan hidup bersih dan sehat pada tatanan rumah tangga di Desa Payangan Wilayah Kerja Puskesmas Marga I Tabanan. Nilai kekuatan korelasi sebesar 0,524 (kekuatan sedang) dan arah korelasi positif $(+)$ artinya semakin baik sikap keluarga terkait dengan hidup bersih dan sehat, maka semakin baik pula penerapan hidup bersih dan sehatnya, begitu sebaliknya semakin kurang sikap keluarga terkait dengan hidup bersih dan sehat, maka akan semakin kurang juga penerapan hidup bersih dan sehat dari keluarga tersebut.

\section{PEMBAHASAN}

\section{Pengetahuan keluarga tentang penerapan hidup bersih dan sehat}

Berdasarkan hasil penelitian di Desa Payangan Wilayah Kerja Puskesmas Marga I Tabanan yang diukur menggunakan kuesioner menunjukkan dari 43 responden, yang memiliki pengetahuan baik sebanyak 19 responden $(44,2 \%)$. Pengetahuan cukup sebanyak 21 responden $(48,8 \%)$, dan pengetahuan kurang 3 responden $(7,0 \%)$. Hal ini menunjukkan bahwa sebagian besar pengetahuan keluarga tentang penerapan hidup bersih dan sehat dikategorikan cukup. 
Hasil dalam penelitian ini sejalan dengan penelitian yang dilakukan oleh Nurjanah (2013), yang berjudul tingkat pengetahuan ibu rumah tangga tentang perilaku hidup bersih dan sehat (PHBS) di Dukuh Keden Wetan menyatakan responden yang memiliki pengetahuan baik sebanyak 6 responden $(15,8 \%)$, pengetahuan cukup sebanyak 27 responden $(71,0 \%)$, dan pengetahuan kurang sebanyak 5 responden $(13,2 \%)$. Hasil ini juga didukung oleh penelitian Carolina (2016), yang berjudul hubungan tingkat pengetahuan dan sumber informasi dengan penerapan PHBS pada keluarga di Wilayah Kerja Pustu Pahandut menyatakan dari 71 responden yang memiliki pengetahuan baik sebanyak 19 responden (27\%), pengetahuan cukup sebanyak 32 responden (45\%), dan pengetahuan kurang sebanyak 20 responden (28\%).

Menurut Notoatmodjo (2012) pengetahuan merupakan hasil dari tahu dan terjadi setelah seseorang melakukan penginderaan terhadap suatu objek tertentu melalui panca indera manusia. Sebagian besar pengetahuan seseorang diperoleh melalui mata dan telinga dan merupakan hal yang sangat penting dalam terbentuknya tindakan seseorang. Pengetahuan erat hubungannya dengan pendidikan, dimana diharapkan dengan pendidikan yang tinggi maka orang tersebut akan semakin luas pula pengetahuannya, tetapi tidak semua orang yang berpendidikan rendah mutlak berpengetahuan rendah. Hal ini mengingat peningkatan pengetahuan tidak mutlak diperoleh dari pendidikan formal. Menurut Soekanto (2011), pengetahuan didapat dari fakta atau kenyataan dengan mendengar dan melihat sendiri melalui alat-alat komunikasi seperti surat kabar, radio, televisi, dan dapat pula diperoleh dari pengalaman berdasarkan pikiran kritis.

Menurut peneliti pengetahuan keluarga tentang penerapan hidup bersih dan sehat secara umum dikatakan cukup baik. Pengetahuan cukup ini didasarkan pada poin pernyataan tentang pemberian ASI eksklusif, mencuci tangan dengan air bersih dan sabun, memberantas jentik nyamuk di rumah, dan tidak merokok, dimana didapatkan dari 43 responden yang menjawab benar mengenai pemberian pendamping ASI bukan merupakan pengertian ASI eksklusif (41,9\%), tidak benar mencuci tangan dengan air saja tanpa sabun $(69,8 \%)$, mencuci tangan sebelum dan setelah melakukan pekerjaan (76,7\%), membakar barang-barang bekas bukan merupakan gerakan $3 \mathrm{M}$ Plus $(34,9 \%)$, dan tidak boleh merokok dimana saja $(58,1 \%)$. Pengetahuan cukup responden juga disebabkan oleh adanya beberapa faktor yang mempengaruhi diantaranya pendidikan. Berdasarkan hasil observasi kuesioner didapatkan 22 responden $(51,2 \%)$ berpendidikan SMP memiliki pengetahuan yang cukup baik, dibandingkan dengan responden yang berpendidikan SMA dan perguruan tinggi yang memiliki pengetahuan baik.

Responden dengan pengetahuan baik pada penelitian ini dapat dilihat berdasarkan poin pernyataan kuesioner, dimana responden menjawab benar mengenai pengertian ASI eksklusif (90,7\%), asi mengandung zat kekebalan terhadap penyakit $(93,0 \%)$, mencuci tangan dengan air yang tidak bersih akan menyebabkan diare $(88,4 \%)$, memberantas sarang nyamuk dapat mencegah penyakit DB (100\%), dan merokok mengakibatkan gangguan paru-paru (100\%), hasil jawaban tersebut yang menyebabkan pengetahuan responden dalam kategori baik. Hal ini juga terkait dengan program puskesmas yang sudah dilaksanakan yaitu pemberian penyuluhan kesehatan tentang PHBS, posyandu yang dilakukan sebulan sekali, dan kegiatan kerja bakti. Sehingga dapat disimpulkan sebagian besar keluarga di Desa Payangan Marga sudah memahami dan mengerti terkait penerapan 
hidup bersih dan sehat. Pengetahuan keluarga yang baik tentang PHBS sangat dipengaruhi oleh kemudahan keluarga dalam mendapatkan informasi kesehatan baik melalui media cetak dan elektronik, maupun promosi kesehatan dari petugas kesehatan.

\section{Sikap keluarga tentang penerapan hidup bersih dan sehat}

Berdasarkan hasil penelitian di Desa Payangan Wilayah Kerja Puskesmas Marga I Tabanan yang diukur menggunakan kuesioner menunjukkan dari 43 responden, yang memiliki sikap baik sebanyak 16 responden $(37,2 \%)$, sikap cukup sebanyak 25 responden $(58,1 \%)$, dan sikap kurang sebanyak 2 responden $(4,7 \%)$. Hal ini menunjukkan bahwa sebagian besar sikap keluarga tentang penerapan hidup bersih dan sehat dikategorikan cukup.

Hasil penelitian ini didukung oleh penelitian yang dilakukan oleh Imam (2015), yang berjudul hubungan tingkat pendidikan dan sikap keluarga dengan perilaku hidup bersih dan sehat di RT 3 RW 07 Kelurahan Pak Uncen Yogyakarta menyatakan bahwa sebanyak 20 responden $(64,5 \%)$ dari total responden menunjukkan sikap yang terbilang cukup mendukung. Penelitian Fitriyah (2011), mendapatkan hasil sebagian besar sikap ibu terkait dengan penerapan hidup bersih dan sehat menunjukan sikap yang cukup baik yaitu sebanyak $70,1 \%$. Berdasarkan hasil penelitian dan beberapa penelitian lain telah menggambarkan bahwa keluarga sudah memiliki sikap cukup baik dalam melakukan penerapan PHBS di tatanan rumah tangga.

Sikap adalah organisasi pendapat, keyakinan seseorang mengenai suatu objek atau situasi yang disertai adanya perasaan tertentu, dan memberikan dasar pada orang tersebut untuk membuat respon atau berperilaku dalam cara tertentu yang dipilihnya (Wawan dan Dewi, 2010). Sikap dapat menimbulkan pola-pola cara berpikir tertentu dalam masyarakat dan sebaliknya, pola-pola cara berpikir ini mempengaruhi tindakan dan kelakuan masyarakat, baik dalam kehidupan seharihari maupun dalam hal membuat keputusan yang penting dalam hidup (Syafni, 2011). Menurut Wawan dan Dewi (2010), pembentukan sikap dipengaruhi oleh beberapa faktor, yaitu pengalaman pribadi, kebudayaan, pengaruh orang lain yang dianggap penting, media massa, lembaga pendidikan dan lembaga agama, serta faktor emosi dalam diri individu. Berbagai bentuk media massa seperti televisi, radio, surat kabar, majalah, dan lain-lain memiliki pengaruh yang besar dalam pembentukan opini dan kepercayaan orang. Sikap ini merupakan kesiapan atau kesediaan untuk bertindak, dan bukan merupakan pelaksanaan motif tertentu. Sikap belum merupakan suatu perilaku, akan tetapi merupakan predisposisi tindakan suatu prilaku (Notoatmodjo, 2012).

Menurut peneliti secara umum sikap keluarga tentang penerapan hidup bersih dan sehat di Desa Payangan Marga sebagian besar dikatakan cukup baik. Berdasarkan pengisian kuesioner menunjukkan bahwa sebagian besar responden setuju terhadap kegiatan terkait penerapan hidup bersih dan sehat. Hal ini terbukti dari jawaban responden yang setuju memberikan ASI saja sampai bayi berusia 6 bulan (67,4\%), setuju ASI yang pertama keluar langsung diberikan pada bayi (72\%), masih ragu mengenai manfaat ASI dan susu formula sama atau tidak (27,9\%), setuju membersihkan sela-sela jari saat mencuci tangan $(81,4 \%)$, masih ragu tentang menggantung pakaian di belakang pintu menjadi masalah atau tidak $(30,2 \%)$, dan setuju anggota keluarga tidak boleh merokok di dalam ruangan 
(60,5\%). Hasil jawaban tersebut yang menyebabkan sikap responden dalam kategori cukup.

Peneliti juga berpendapat bahwa sikap cukup responden juga disebabkan oleh pengalaman pribadi, dimana berdasarkan hasil wawancara peneliti dengan responden pada saat penelitian, faktor yang paling mempengaruhi sikap responden dalam penelitian ini adalah pengalaman pribadi responden yang pernah melihat secara langsung kondisi penderita diare maupun DBD. Pengalaman tersebut membuat responden memiliki sikap positif untuk menghindari penyakit dengan menerapkan hidup bersih dan sehat.

\section{Penerapan hidup bersih dan sehat keluarga pada tatanan rumah tangga}

Berdasarkan hasil penelitian di Desa Payangan Wilayah Kerja Puskesmas Marga I Tabanan yang diukur menggunakan kuesioner menunjukkan dari 43 responden, yang memiliki penerapan hidup bersih dan sehat baik sebanyak 8 responden $(18,6 \%)$, penerapan hidup bersih dan sehat cukup sebanyak 20 responden $(46,5 \%)$, dan yang memiliki penerapan hidup bersih dan sehat kurang sebanyak 15 responden $(34,9 \%)$. Hal ini menunjukkan bahwa sebagian besar responden memiliki penerapan hidup bersih dan sehat yang cukup. Tindakan merupakan perwujudan sikap, namun untuk mewujudkan sikap menjadi satu perbuatan yang nyata tetap diperlukan pendukung atau kondisi yang memungkinkan seperti fasilitas (Notoatmodjo, 2007).

Hasil penelitian ini sejalan dengan penelitian yang dilakukan oleh Carolina (2016), yang menyatakan bahwa responden yang memiliki penerapan PHBS yang baik sebanyak 8 responden (11\%), penerapan PHBS cukup sebanyak 44 responden (62\%), dan yang memiliki penerapan PHBS kurang sebanyak 19 responden (27\%). Sejalan juga dengan penelitian Artini (2010), menyatakan sebagian besar keluarga sudah menerapkan PHBS di tatanan rumah tangga dengan baik yaitu sebanyak $75 \%$.

Paradigma sehat dijabarkan dan dioperasionalkan antara lain dalam bentuk perilaku hidup bersih dan sehat. Notoatmodjo (2007) mencoba menganalisa perilaku manusia dari tingkat kesehatan. Kesehatan seseorang atau masyarakat dipengaruhi oleh 2 faktor pokok, yakni faktor perilaku dan faktor diluar perilaku. Selanjutnya perilaku itu sendiri ditentukan oleh 3 faktor, yaitu faktor predisposisi, yang terwujud dalam pengetahuan, sikap, kepercayaan, nilai-nilai dan sebagainya, faktor pendukung yang terwujud dalam lingkungan fisik, tersedia atau tidaknya fasilitas-fasilitas atau sarana-sarana kesehatan, dan faktor pendorong, yang terwujud dalam sikap dan perilaku petugas kesehatan, atau petugas lain yang merupakan kelompok referensi dari perilaku masyarakat. Teori Green mengungkapkan bahwa pengetahuan dan sikap menentukan baik buruknya perilaku seseorang untuk meningkatkan kesehatan.

Menurut peneliti penerapan hidup bersih dan sehat keluarga di Desa Payangan dalam kategori cukup, hal ini dapat dilihat dari pengisian kuesioner dimana responden masih belum menerapkan hidup bersih dan sehat dengan baik. Terkait dengan pengelolaan sampah dan barang bekas sebagian besar responden masih membakar barang-barang bekas untuk memberantas sarang nyamuk $(62,8 \%)$, hal tersebut disebabkan karena responden kesulitan mengelola sampah dan barangbarang bekas dikarenakan kurangnya sosialisasi terkait dengan adanya TPA. Terkait menguras tempat penampungan air sebagian besar responden menguras 
tempat penampungan air secara tidak rutin $(53,5 \%)$ dan tidak menaburkan bubuk abate $(67,4 \%)$. Berdasarkan hasil wawancara, responden belum memahami betul tentang pentingnya penaburan bubuk abate dan menguras tempat penampungan air sebagai tindakan preventif terkait dengan kegiatan PSN. Terkait dengan perilaku merokok didapatkan sebagian besar responden $(74,4 \%)$ memiliki anggota keluarga dengan kebiasaan merokok, berdasarkan hasil wawancara dengan responden, merokok disebabkan oleh kebiasaan yang tidak bisa dihindari oleh anggota keluarga. Hal tersebut menunjukkan penerapan hidup bersih dan sehat keluarga masih dalam kategori cukup, sehingga diperlukan peran petugas kesehatan demi meningkatkan penerapan hidup bersih dan sehat dalam keluarga.

\section{Hubungan pengetahuan keluarga dengan penerapan hidup bersih dan sehat pada tatanan rumah tangga}

Hasil uji statistik menunjukkan bahwa terdapat hubungan yang bermakna antara pengetahuan keluarga dengan penerapan hidup bersih dan sehat pada tatanan rumah tangga didapatkan nilai $\mathrm{p}$ value $=0,001(\mathrm{p}<0,05)$ maka Ho ditolak dan hipotesis penelitian (Ha) diterima, yang artinya ada hubungan yang signifikan antara variabel pengetahuan keluarga dengan penerapan hidup bersih dan sehat pada tatanan rumah tangga di Desa Payangan Wilayah Kerja Puskesmas Marga I Tabanan. Nilai kekuatan korelasi sebesar 0,477 (kekuatan sedang) dan arah korelasi positif (+) artinya semakin baik pengetahuan keluarga terkait dengan hidup bersih dan sehat, maka semakin baik pula penerapan hidup bersih dan sehatnya, begitu sebaliknya semakin kurang pengetahuan keluarga terkait dengan hidup bersih dan sehat, maka akan semakin kurang juga penerapan hidup bersih dan sehat dari keluarga tersebut. Hasil penelitian ini sesuai dengan teori Notoatmodjo (2007), menyatakan bahwa pengetahuan merupakan faktor predisposisi untuk mencapai perilaku positif.

Hasil ini didukung oleh penelitian yang dilakukan oleh Carolina (2016), yang menyatakan bahwa terdapat hubungan yang signifikan antara tingkat pengetahuan dengan penerapan PHBS pada keluarga di Wilayah Kerja Pustu Pahandut dengan nilai $\mathrm{p}$ value $=0,000<0,05$. Dikuatkan juga oleh penelitian Fitriyah (2011), menyatakan bahwa terdapat hubungan antara pengetahuan dengan pelaksanaan indikator PHBS rumah tangga di Wilayah Kerja Puskesmas Kayamanya Kabupaten Poso dengan nilai $\mathrm{p}$ value $=0,003<0,05$.

Menurut Wawan dan Dewi (2010), Pengetahuan atau kognitif merupakan domain yang sangat penting dalam membentuk tindakan seseorang (overbehavior), perilaku yang di dasari oleh pengetahuan akan lebih langgeng dari perilaku yang tidak di dasari oleh pengetahuan. Pengetahuan yang baik akan membantu seseorang untuk memahami, mengaplikasikan, dan menganalisa setiap perilaku secara baik pula. Perilaku seseorang tidaklah dapat dipisahkan dengan tingkat pengetahuan orang tersebut, terlebih lagi dalam kaitannya dengan perilaku kesehatan yang terkadang masih merupakan sesuatu yang sangat awam bagi sebagian kalangan masyarakat.

Pengetahuan responden dipengaruhi oleh faktor umur dan pendidikan, sedangkan perilaku responden selain dipengaruhi oleh pengetahuan juga dipengaruhi oleh motivasi dalam dirinya. Pendidikan telah memberikan wawasan yang cukup luas sehingga sesorang akan mampu meningkatkan pengetahuannya untuk menghadapi masalah kesehatan yang dihadapi. Pendidikan yang dimaksudkan bukan hanya pendidikan formal saja, tetapi juga pendidikan 
nonformal di tempat-tempat umum seperti penyuluhan di masyarakat, rumah sakit atau media masa, sehingga pengetahuan tentang hidup bersih dan sehat dengan penerapan hidup bersih dan sehat dapat dilakukan dengan maksimal.

Menurut peneliti pengetahuan memiliki kekuatan hubungan yang sedang dengan penerapan hidup bersih dan sehat, hal tersebut ditunjukan berdasarkan hasil dan observasi selama penelitian didapatkan pengetahuan memiliki hubungan sebesar $47,7 \%$. Hasil tersebut disebabkan adanya faktor lain yang mempengaruhi penerapan hidup bersih dan sehat keluarga, terlihat sebanyak 4,7\% (2 orang responden) memiliki pengetahuan baik dan penerapan kurang, hal tersebut disebabkan adanya faktor lain yang mempengaruhi salah satunya adalah faktor fasilitas yang tersedia, sehingga meskipun keluarga memiliki pengetahuan baik tetapi jika tidak didukung dengan adanya fasilitas yang memadai maka keluarga tidak akan mampu menerapkan hidup bersih dan sehat yang dianjurkan.

\section{Hubungan sikap keluarga dengan penerapan hidup bersih dan sehat pada tatanan rumah tangga}

Hasil uji statistik menunjukkan bahwa terdapat hubungan yang bermakna antara sikap keluarga dengan penerapan hidup bersih dan sehat pada tatanan rumah tangga didapatkan nilai $\mathrm{p}$ value $=0,000(\mathrm{p}<0,05)$ maka Ho ditolak dan hipotesis penelitian (Ha) diterima, yang artinya ada hubungan yang signifikan antara variabel sikap keluarga dengan penerapan hidup bersih dan sehat pada tatanan rumah tangga di Desa Payangan Wilayah Kerja Puskesmas Marga I Tabanan. Nilai kekuatan korelasi sebesar 0,524 (kekuatan sedang) dan arah korelasi positif $(+)$ artinya semakin baik sikap keluarga terkait dengan hidup bersih dan sehat, maka semakin baik pula penerapan hidup bersih dan sehatnya, begitu sebaliknya semakin kurang sikap keluarga terkait dengan hidup bersih dan sehat, maka akan semakin kurang juga penerapan hidup bersih dan sehat dari keluarga tersebut.

Hal ini sejalan dengan hasil penelitian yang dilakukan oleh Kastari (2016), di Wilayah Kerja UPK Puskesmas Telaga Biru Kelurahan Siantan Hulu Pontianak Utara menyatakan bahwa responden yang memiliki sikap baik akan diikuti dengan tindakan baik juga. Keadaan ini sesuai dengan teori yang menyatakan bahwa sikap merupakan salah satu faktor predisposisi seseorang untuk bertindak. Sikap bukan dibawa sejak lahir, namun sikap dapat dibentuk dari adanya interaksi sosial yang dialami oleh responden. Dalam interaksi sosial tersebut terjadi hubungan timbal balik yang saling mempengaruhi diantara individu yang dapat mempengaruhi pola tindakan dan perilaku dalam berinteraksi dengan lingkungannya. Pembentukan sikap dipengaruhi oleh beberapa faktor yaitu pengalaman pribadi, kebudayaan, pengaruh orang lain yang dianggap penting, media massa, lembaga pendidikan dan lembaga agama, faktor emosi dalam diri individu (Wawan dan Dewi, 2010).

Menurut peneliti sikap memiliki kekuatan hubungan yang sedang dengan penerapan hidup bersih dan sehat, hal tersebut ditunjukan berdasarkan hasil dan observasi selama penelitian didapatkan sikap memiliki hubungan sebesar 52,4\%. Hasil tersebut disebabkan adanya faktor lain yang mempengaruhi penerapan hidup bersih dan sehat keluarga, terlihat dari 16 responden $(37,2 \%)$ dengan sikap baik menunjukkan sebanyak 10 responden $(23,3 \%)$ memiliki penerapan hidup bersih dan sehat cukup, hal tersebut disebabkan adanya faktor lain yang mempengaruhi salah satunya adalah faktor kebiasaan. Keluarga mengerti bahwa merokok merupakan perilaku yang tidak baik untuk kesehatan tetapi masih terdapat $(74,4 \%)$ 
responden memiliki anggota keluarga yang merokok, hal tersebut disebabkan oleh adanya faktor kebiasaan pada anggota keluarga sehingga sulit untuk merubah kebiasaan yang dimilikinya, meskipun sikap keluarga tersebut tidak setuju dengan perilaku merokok. Jadi dapat disimpulkan, sikap seseorang akan menentukan tindakan yang dilakukan oleh orang tersebut. Melalui sikap, masyarakat mampu untuk memahami proses kesadaran yang menentukan tindakan nyata yang mungkin dilakukan oleh seseorang.

\section{SIMPULAN DAN SARAN}

\section{SIMPULAN}

Semakin baik pengetahuan keluarga maka akan semakin baik penerapan hidup bersih dan sehatnya, sehingga keluarga yang memiliki pengetahuan baik akan mampu menerapkan hidup bersih dan sehat dengan baik. Sikap keluarga juga mempengaruhi penerapan hidup bersih dan sehat, keluarga yang memiliki sikap baik akan mampu menerapkan hidup bersih dan sehat dengan baik.

\section{SARAN}

Masih diperlukan penelitian lebih lanjut tentang pengetahuan dan sikap sebagai salah satu faktor yang mempengaruhi PHBS serta sebagai upaya dalam peningkatan pelayanan oleh profesi keperawatan terkait hasil penelitian untuk dapat digunakan atau diaplikasikan dalam promosi kesehatan.

\section{DAFTAR PUSTAKA}

Artini, N., 2010. Hubungan Pengetahuan dan Sikap Orang Tua Bayi dengan Penerapan Perilaku Hidup Bersih dan Sehat di Puskesmas Pasundan Samarinda Kalimantan Timur. Tesis. Tidak dipublikasikan. Universitas Sebelas Maret.

Carolina, 2016. Hubungan Tingkat Pengetahuan dan Sumber Informasi dengan Penerapan Hidup Bersih dan Sehat Pada Keluarga di Wilayah Kerja Pustu Pahandut Seberang Kota Palangkaraya. Enviro Scienteae. 12(3), 330-337

Dinas Kesehatan Kabupaten Tabanan, 2016. Laporan Tahunan Pelayanan Kesehatan Masyarakat.

Dinkes Provinsi Bali, 2016. Profil Kesehatan Provinsi Bali 2015. Bank Data. (Online) (http://www.diskes.baliprov.go.id., diakses tanggal 15 Januari 2017, jam 13.00 WITA)

Fitriyah, 2011. Faktor-Faktor yang Berhubungan dengan Pelaksanaan Indikator Perilaku Hidup Bersih dan Sehat Pada Rumah Tangga di Wilayah Kerja Puskesmas Kayamanya, Kabupaten Poso. Promotif. 2(2), 102-110

Imam, 2015. Hubungan Tingkat Pendidikan dan Sikap Keluarga dengan Perilaku Hidup Bersih dan Sehat di RT 3 RW 07 Kelurahan Pak Uncen Wirobrajan Yogyakarta. Jurnal Kesehatan. (Online) (http://opac.unisayogya.ac.id., diakses tanggal 16 April 2017, jam 13.00 WITA)

Kastari, 2016. Faktor-Faktor yang Berhubungan dengan Pelaksanaan Perilaku Hidup Bersih dan Sehat (PHBS) Rumah Tangga di Wilayah Kerja UPK Puskesmas Telaga Biru Kelurahan Siantan Hulu Pontianak Utara. Jurnal Keperawatan. (Online) (http://litbang.poltekkespontianak.ac.id., diakses 
tanggal 16 April 2017, jam 13.00 WITA)

Kemenkes RI, 2015a. Profil Kesehatan Indonesia 2014. Jakarta: Kemenkes RI

Kemenkes RI, 2015b. Rencana Strategi Kementerian Kesehatan tahun 2015-2019. Jakarta: Kemenkes RI

Notoatmodjo, 2007. Promosi Kesehatan dan Ilmu Perilaku. Jakarta : Rineka Cipta. Notoatmodjo, 2012. Promosi Kesehatan dan Ilmu Perilaku. Jakarta: Rineka Cipta

Nurjanah, 2013. Tingkat Pengetahuan Ibu Rumah Tangga Tentang Perilaku Hidup Bersih dan Sehat (PHBS) di Dukuh Keden Wetan, Kelurahan Keden, Kecamatan Kalijambe, Kabupaten Sragen. Skripsi. Tidak dipublikasikan. STIKes Kusuma Husada Surakarta

Proverawati \& Rahmawati, 2012. Perilaku Hidup Bersih dan Sehat (PHBS). Yogyakarta: Nuha Medika

Puskesmas Marga I, 2016. Laporan Tahunan Pelayanan Kesehatan Masyarakat. Tabanan: Puskesmas Marga I

Rakorpop Kemenkes RI., 2015. Kesehatan dalam Kerangka Sustainable Development Goals (SDGS). Jakarta: Kemenkes RI

Riskesdas, 2013. Laporan Nasional. Jakarta: Badan Litbangkes Depkes

Soekanto, 2011. Sosiologi Suatu Pengantar. Jakarta: PT. Raja Grafindo Persada

Syafni, 2011. Hubungan Pengetahuan dan Sikap Keluarga tentang PHBS dengan Penerapan PHBS di Tatanan Rumah Tangga. Available : https://www.scribd.com/document/336254813/skripsi-PHBS. (15 Januari 2016).

Wawan, A. dan Dewi, M., 2010. Teori \& Pengukuran Pengetahuan, Sikap, dan Perilaku Manusia. Yogyakarta: Nuha Medika

WHO, 2011. The World Health Report 2011; Reducing Risks, Promoting Healthy Life. Geneva: WHO 